\title{
The Institution of the Court in Modern Russian Society: The Problem of Public Trust
}

\author{
Yaroslava Zinchenko ${ }^{1}{ }^{*}$ Anastasia Makarova ${ }^{2}$, Valeria Provotorova ${ }^{3}$ \\ ${ }^{1}$ South-Russia Institute of Management - branch of Russian Presidential Academy of National Economy and Public \\ Administration, Russia \\ ${ }^{2}$ The Arbitration Court of the North Caucasus District, Russia \\ ${ }^{3}$ The 15 Arbitration Court of Appeal, Russia \\ *Email: yazinchenko@uriu.ranepa.ru
}

\begin{abstract}
The purpose of the article is to study the problem of trust of Russians in the judicial system. The court is considered as a social institution that regulates the legal and social order. Its institutional features and stages of institutionalization of the modern Russian judicial system are highlighted. The methods of sociological analysis of dysfunctions of the Institute of the court are presented. The approaches to the definition of institutional trust are considered, and its types are highlighted. The article presents an analysis of public assessments of the judicial system, as well as ratings of international research organizations that characterize public opinion regarding the activities of the courts. The author suggests measures to strengthen the authority of the judicial system in the public consciousness of Russians. The question is raised about the need to conduct interdisciplinary research on trust in the judicial system, as well as to involve the professional community, educational institutions, the media, public and human rights associations in the discussion on this issue.
\end{abstract}

Keywords: Institution of the court, Judicial system, Trust, Dysfunctions.

\section{INTRODUCTION}

For almost three decades, the country's judicial system has been virtually being re-formed in accordance with the Constitution and Federal legislation, as well as modern trends in informatization and transparency of public administration.

At the same time, for modern society - postmodern society, with its constantly growing uncertainty and unbalanced social structures, one of the most problematic issues is trust, including in the structures of state power.

It is difficult to overestimate the importance of trust, because this social phenomenon is the basis for the stable functioning of state and civil society institutions, as well as for the legal and social order

At the same time, the researchers from various fields of scientific knowledge: lawyers, philosophers, sociologists, psychologists, and political scientists record a situation of lack of confidence in the activities of judicial authorities.

This encourages us to turn to the sociological perspective of the court's analysis, consider it as a social institution, and explore the social anatomy of the phenomenon of citizens' trust in the judicial system.

The article is based on the methodological principles of the institutional approach, analysis of text documents, and secondary analysis of sociological data.

\section{INSTITUTE OF THE COURT IS A REGULATOR OF LEGAL AND SOCIAL ORDER}

Stable functioning of society implies the normative consolidation of a number of social relations, the construction of typified models of human behavior, their internalization in the consciousness of individuals and in mandatory practices of social activity.

Legal relations that consolidate social order, ensure the effective functioning of the state, balance group interests, i.e., satisfy social needs are transformed into social institutions.

A social institution is an organized system of relations, which is a value-normative complex, through which people's actions to meet the basic needs of society are directed and controlled [1]. 
Presenting the court as a social institution it is necesssary to note that the value-normative complex in this case is represented by a valuable unit that includes values of the rule of law, legality and the normative standardized sample of behavior, originating in the Constitution and other Federal legislation; the system of communication in this case is represented by a configuration of social roles and statuses (the president of the court, judge, etc.), within which the behavioral model is implemented.

Let's consider the signs of a social institution in relation to the court.

The purpose of the court is to administer justice in the form of civil, constitutional, criminal, administrative and arbitration proceedings.

Functions are the protection of violated or disputed rights, maintenance of the rule of law, as well as legal and social order, prevention of delinquent behavior through educational work, interpretation of legislation, control, and fact-finding.

A set of social statuses and roles are court presidents, federal and magistrate judges, employees of court apparatuses.

Depersonalization of status and role requirements is provided by the qualification requirements of official regulations.

The key values are the rule of law, legality, equality before the law, transparency, independence and independence.

Norms - the Constitution and other legislation of the Russian state.

Regulation - the creation, operation, and abolition of courts and the empowerment of judges are determined by the relevant federal laws.

System of sanctions means failure to comply with a court order, as well as disrespect for it, entail liability provided for by the relevant legislation.

Presence of controlling and regulating institutions higher courts perform a control and supervisory function in relation to compliance by lower courts with the legislation of the Russian Federation.

The division of labor involves the following categories of employees: judges, court staff, technical specialists.

Professionalization is provided by organizations that implement educational programs of higher, additional professional, and postgraduate education, as well as by the activities of the judicial community.

Cultural symbols are the elements of state symbols that are placed on court buildings and in courtrooms, and judges sit in robes.
So, the court is one of the most important social institutions that regulates the legal and social order, protects the rights of citizens, and resolves social conflicts in society. It is necessary to consider the process of institutionalization of the court in the Russian Federation.

\section{FORMATION OF THE INSTITUTION OF THE COURT IN THE RUSSIAN FEDERATION}

Institutionalization is the process of ordering publiclegal relations, defining and fixing the relevant norms, statuses and roles, bringing them into a system that can meet the needs of society in strengthening order and stability [1].

The institutionalization process includes three phases. At the first stage, there is an actualization of the public need for a professional judicial corps capable of performing the functions of justice. Independent judicial power appears in Russia in the course of the judicial reform of 1864, inspired by the ideas of the French educator Sh.L. Montesquieu. The modern model of the Russian judiciary, which can be dated back to 1991, when the Supreme Soviet of the RSFSR adopted the Concept of judicial reform, was the successor to the Imperial model.

In the second phase, norms and values are internalized and a code of conduct is approved. In 1992, federal legislation defined the status of judges. The following year, with the adoption of the Constitution, the foundations of the court were fixed.

The third phase of institutionalization of the court is related to organizational design. In 1996, the legislator forms the system of judicial bodies, determines their structure and procedure of legal proceedings. In the new millennium, all types of courts provided for by law are being established, new codes of procedure are being adopted, courts with the participation of the public jurors - are being introduced, and world justice is being revived. Changes in the judicial system are made within the framework of the program-target approach, through interdepartmental implementation of target programs.

Much of the reform that has not yet been completed, and therefore the institutionalization of the judicial system, concerns the principles and mechanisms of the court's functioning.

\section{FUNCTIONING OF THE INSTITUTE OF THE COURT}

The effective functioning of the judicial system is a key element in the formation of social order and the rule of law. 
Let us consider the universal functions of social institutions in relation to the court.

The function of consolidating and reproducing public relations is expressed in a system of norms that define the statuses, roles, and standards of interaction between citizens in judicial proceedings with each other and representatives of the judicial community.

The regulatory function is embodied in the development of patterns of behavior, role requirements and expectations of participants in legal proceedings.

The integrative function is provided by the execution of judicial proceedings on the principle of equality of all before the law, measures to strengthen the authority of the court and judges, and increase public confidence in the judicial system.

The broadcasting function is expressed in the transfer of organizational culture, professional experience, and educational activities of the court to new generations of judges and staff.

The communication function is implemented through information systems for access of participants in court proceedings to the materials of court decisions, as well as through the activities of public relations and media services.

The main functions of the court are the elementary components of the function of the administration of justice, they include: legal protection and ensuring the balance of public and private interests.

Subsidiary functions of the court are: restraint of the legislative and executive branches of state power, its legal consolidation, system support of law and legal priority in legal regulation, legitimation of state power, educational function, law-initiating function.

Among the auxiliary functions, special attention is paid to such functions as the function of hierarchical self-regulation and unification of judicial practice, the function of legal interpretation and legal specification, the function of ensuring the availability of justice, and the function of judicial self-government [2].

The implementation of these functions pursues a single goal - the protection of the rights and freedoms of both an individual subject (citizen, legal entity) and the entire society (the formation of a common legal field of the state). At the same time, the court, as part of the system of state bodies, should not violate the principle of sovereign development of statehood, but at the same time limit state power by law.

The consequences of non-compliance with this balance in the judicial system manifest themselves in dysfunctions that arise in the process of implementing the activities of specific judicial bodies. The manifestation of the domineering nature of the judicial system contradicts the tasks and meaning of the main function - the administration of justice.

The reform of the court's activities should first of all be carried out to improve the quality and accessibility of justice. However, in practice, there are conflicts. For example, when solving the issue of reducing the judicial burden, attempts are made to typologize judicial acts on similar disputes, and to abandon the motivational part when issuing a judicial act in simplified proceedings. However, these actions aggravate other issues, in particular, citizens' trust in the judiciary.

In addition, it is possible to trace the bureaucratization of the judicial system even in the statistical indicators of the effectiveness of the courts represented by the Supreme Court of the Russian Federation. The main indicator is the number of cancellations of judicial acts. At the same time, this indicates the stability, but not always the legality of the adopted judicial act, and orients a particular judge to issue a judicial act in the established "unified practice" without focusing on the specific circumstances of the case.

As the European court of human rights has repeatedly pointed out in its rulings, "the dysfunction of the justice system as a result of non-execution or late execution of domestic decisions poses an important threat to the rule of law, diminishes the people's trust in the judicial system and calls into question the trust in the state" [3].

The above circumstances indicate the need for a sociological analysis of such an element of the social order as trust in the judicial system in the next part of the article.

\section{TRUST IN THE JUDICIAL SYSTEM}

Trust has recently become a popular subject of interdisciplinary research both in Russia and abroad. Its legal, psychological, and sociological aspects are investigated, and ratings and indexes are formed. Various manifestations of trust are analyzed: interpersonal, social, institutional, organizational, business, etc.

Geoffrey Hosking, the Professor at the school of Slavic and Eastern European studies at the University of London, gives the following definition of trust: 1) attachment to a person, a group of individuals, or an institution based on a well-founded but undefined expectation that he / she / they will act for my / our good; 2) expectation based on good but far from perfect evidence that events will develop without harm to me / us [4].

Trust is a fundamental element of socially cohesive societies. It is therefore essential to understand and explain differences in trust and social cohesion. Ruud 
Koopmans, a well-known sociologist and Professor at the Humboldt University of Berlin, defines social cohesion as the ability of a community to act collectively in the pursuit of public goods, as well as the attitudes and expectations that underlie this ability [5].

Correlating the concepts of public trust and social cohesion, sociologist Bram Lancee, the associate Professor at the University of Amsterdam, emphasizes that social cohesion refers to a set of attitudes that express a certain degree of confidence in other people or institutions and shared values and norms, as well as a set of (behavioral) indicators that reflect social networks, civic participation, intergroup contacts, and the like [6].

Since the justice system is a complex institutional environment that includes the police, courts, prosecutor's offices, and prisons, potential trust relationships with the justice system also offer a complex picture, since they can move between different social actors in different directions. The Head of the Department of democratic and political theory at the centre for social sciences of Hungarian Academy of Sciences Zsolt Boda notes that can be distinguished: public confidence in justice institutions; trust the justice system to people; trust in the justice system, between its institutions and participants [7].

Roy J Lewicki, the Professor in the Department of human resources and business ethics of College of business at the Ohio State University, identifies three types of trust in the public sector: calculus-based trust; knowledge-based trust; and identification-based trust [8].

The prospects for the development of knowledgebased trust by state structures are related to the fact that it can develop in many ways simultaneously. Steven Van de Walle, the professor of public administration and public management at the Institute of public administration at the Catholic University of Leuven, notes that adding information to a relationship allows you to interpret the actions of another and makes interactions predictable. Maintaining such trust, of course, requires significant amounts of information and monitoring tools, but these efforts have such positive effects as the development of legislation on freedom of information, access to open data, and the availability of information about the results of state institutions ' activities [9].

Two key conceptual documents containing directions for the development of the judicial system in the Russian Federation are also addressed to the issue of public trust. These are the Concept of the Federal target program "Development of the Russian judicial system for 2013-2020" and The concept of information policy of the judicial system for 2020-2030.

In the Federal target program that ends its term this year, the strengthening public confidence in the judicial system is not considered a separate task, but is designated as one of the key indicators of successful implementation of the program's activities. In accordance with the realistic scenario of the program, by 2020 , it was planned to reduce the share of citizens who consider the work of the courts unsatisfactory to $5 \%$. At the same time, professional research sociological organizations record the following public assessments in 2020 .

VTSIOM for September 2020 shows $44.7 \%$ of citizens who do not approve of the judicial system, placing it in the opposition $(44.8 \%)$ and the media $(44.3 \%)$ [10].

The FOM for August 2020 indicates a figure of 41 $\%$ of those who have a negative attitude to the activities of courts and judges [11].

In September 2019, the Levada center indicates the following data on institutional trust for the courts: not quite deserving $-35 \%$, not at all deserving $-24 \%$ [12]

There are also international ratings that characterize public opinion regarding the activities of courts. For example, the Rule of Law Index, a study by the international non-governmental organization The World Justice Project, compiled annually on the basis of publicly available statistical data and sociological surveys of legal experts, puts the Russian Federation in 93rd place out of 128 states. It is worth noting that two of the eight benchmarks are civil and criminal justice [13].

According to the results of the European Social Survey (ESS), $47.2 \%$ of Russians do not trust the national judicial system [14].

The World Bank Rating - The Doing Business index puts Russia in 28th place in 2019, raising it by 3 positions up, compared to last year [15]. This rise is largely due to positive assessments of the quality of the judicial system (meaning the activity of arbitration courts), the time of dispute resolution and the cost of judicial procedure. It should be noted that according to the Center for the development of modern law, there are factual errors in the 2019 rating, without which Russia would have taken 26th place in the rating [16].

According to the review of the confidence barometer - Edelman Trust Barometer, the General index of public confidence in Russia in 2019, is 28 points out of 100 . The research is conducted in four areas: government, business, non-profit organizations, and the media. All these sectors are characterized by serious distrust of Russians, but citizens do not trust state institutions to a lesser extent than others [17].

In general, it is necessary to note the need for a balanced approach to assessing the representativeness of data from international non-governmental research organizations. It is appropriate to refer not only to the 
positions of countries in the ratings, but also to the sources of funding for these organizations, taking into account their possible bias, as well as the politicization of data.

Thus, we can conclude that the sociological data of Russian and international research organizations are similar to the relatively low assessment of the activities of Russian courts, as well as that the target indicator was not achieved in the course of implementing the Federal target program.

At the same time, it should be noted that conducting annual public opinion polls on the activities of courts was assigned to the competence of the Ministry of economic development of the Russian Federation. The analysis of text documents - reports on the implementation of the program for 2013-2020 showed that none of the reports contain data from sociological surveys ordered on 30.10.2013. The Ministry of economic development by a state contract with LLC "InvestHors", an organization that does not have in the Internet any information resource, introducing the nature of its activities. The summary table of target indicators shows data only for 2013: it was planned to achieve the indicator of $18 \%$ - the share of citizens who consider the organization of work of courts unsatisfactory, in fact, it was $24.5 \%$. At the same time, as of July 2013, the number of persons who negatively assess the activities of courts and judges according to the FOM was $35 \%$. It is also worth noting that the reports for the final 2019-2020 years did not plan activities in the direction of $R \& D$, and state customers were recommended to take comprehensive measures to achieve all the target indicators and indicators of the program [18].

The goal of increasing the level of confidence in the judicial system is set in the sixth position in the target block of the current Concept of information policy of the judicial system for 2020 - 2030. According to the judicial community, this goal can be realized by popularizing knowledge about the judicial system and in this regard, interaction with representatives of the expert community who monitor (survey) public opinion on the activities of the judicial system, as well as conduct sociological research aimed at improving the effectiveness of interaction between the judicial authorities and the media is singled out as an independent direction of information policy implementation [19].

Thus, we can conclude that it is necessary to conduct professional, reliable, representative sociological research to determine relevant and appropriate areas for strengthening the authority of courts and judges of the Russian Federation with the involvement of research teams formed from representatives of both the sociological and legal scientific community.

\section{CONCLUSIONS}

Strengthening the authority of the court, representatives of the judicial community, and increasing institutional confidence in the judicial system are complex tasks that the state has been trying to solve for almost a decade, spending budget funds within the framework of Federal targeted programs.

For the next ten years, the solution of these tasks has been conceptually defined by the judicial corps itself, and this positive signal from the professional community should be perceived by representatives of social sciences, educational institutions, the media, public and human rights associations.

An interdisciplinary methodology that makes it possible to correctly diagnose public attitudes and monitor media content will help develop adequate ways to increase confidence in the court, and support from educational institutions at different levels and establish a constructive dialogue with the public and the journalistic community will consolidate the positive trend.

\section{AUTHORS' CONTRIBUTION}

Yaroslava Zinchenko - $40 \%$

Anastasia Makarova - $30 \%$

Valeria Provotorova - $30 \%$

\section{REFERENCES}

[1] G.P. Zinchenko, Ya.G. Zinchenko, Public service: sociological essays: monograph, Moscow: University book, 2013. p. 21 (In Russ.).

[2] S.B. Polyakov, Self-supporting function of the judicial power, Arbitration and civil process 5 (2018) 3-9 (In Russ.).

[3] ECHR Ruling of 12.10.2017 "The Case of Burmych and others against Ukraine" (complaint No. 46852/13 and others), Precedents of the European Court of human rights. Special issue, No. 3(15), 2018 (In Russ.).

[4] G. Hosking, «Trust in the trustworthy: a key to social cohesion?» in H. Prange-Gstöhl (Ed.), Trust at risk? Implications for EU policies and institutions, 2017, pp. 8-16, Publications Office of the European Union, Luxembourg. Retrieved from: //https://op.europa.eu/en/publication-detail//publication/e512c11b-e922-11e6-ad7c$\underline{01 \text { aa75ed71a1 }}$

[5] Koopmans, Ruud/Lancee, Bram/Schaeffer, Merlin (editors) (2015), Social cohesion and Immigration in Europe and North America: Mechanisms, 
conditions and causality. London/New York: Routledge, 2015, p. 2. Retrieved from: //https://www.researchgate.net/publication/284416 070 Ethnic diversity in diverse societies An int roduction

[6] Lancee, Bram, Diversity, trust and social cohesion. Heiko, Prange-Gstöhl (szerk.) Trust at Risk: Implications for EU Policies and Institutions Brussels, Belgium: European Commission, 2017, pp. 167-175. Retrieved from: //http://publications.europa.eu/resource/cellar/e512 c11b-e922-11e6-ad7c01aa75ed71a1.0001.01/DOC _ 1

[7] Boda, Zsolt. Trust in Justice, Heiko, Prange-Gstöhl (szerk.) Trust at Risk: Implications for EU Policies and Institutions Brussels, Belgium: European Commission, 2017, pp. 152-166. Retrieved from: //http://publications.europa.eu/resource/cellar/e512 c11b-e922-11e6-ad7c01aa75ed71a1.0001.01/DOC_1

[8] Lewicki, Roy J./Bunker, Barbara B., Developing and maintaining trust in work relationships, in: Kramer, Roderick M./Tyler, Tom R. (eds.), Trust in organizations: Frontiers of theory and research. Thousand Oaks: Sage publications, 1996, pp. 114$139 . \quad$ Retrieved from: //https://www.researchgate.net/publication/234021 697 Developing and Maintaining Trust in Work ing Relations

[9] Van de Walle, Steven. Trust in public administration and public services. Heiko, PrangeGstöhl (szerk.) Trust at Risk: Implications for EU Policies and Institutions Brussels, Belgium: European Commission, 2017, pp. 118-128. Retrieved from: //http://publications.europa.eu/resource/cellar/e512 c11b-e922-11e6-ad7c$\underline{01 \mathrm{aa} 75 \mathrm{ed} 71 \mathrm{a} 1.0001 .01 / \mathrm{DOC} \quad 1}$

[10] All-Russian center for public opinion research [Electronic resource]. Activities of public institutions. Retrieved from: https://wciom.ru/news/ratings/odobrenie deyatelno $\underline{\text { sti_obshhestvennyx institutov/ (accessed }}$ 30.10.2020) (In Russ.).

[11] Fund "Public opinion" [Electronic resource]. Work of courts and judges. Ideas about justice, independence and selflessness of judges. Retrieved from: https://fom.ru/Bezopasnost-i-pravo/14459 (accessed 30.10.2020) (In Russ.).

[12] Levada-Center [Electronic resource]. Institutional trust. https://www.levada.ru/2019/10/24/institutsionalnoe -doverie-5/ (accessed 30.10.2020) (In Russ.).

[13] The WJP Rule of Law Index and the World Justice Project Rule of Law Index are trademarks of the World Justice Project. Retrieved from: //https://worldjusticeproject.org/our-work/researchand-data/wjp-rule-law-index-2020

[14] V.A. Prohoda, Trust of Russians in the national judicial and legal system (based on the materials of a sociological study), Sociodynamics 5 (2019) 8694 (In Russ.).

[15] Doing Business, Comparing Business Regulation in 190 Economies, World Bank Group, 2020 Retrieved from: //https://www.doingbusiness.org/en/reports/globalreports/doing-business-2020

[16] Quality of economic justice in the Russian Federation: reality v. Doing Business-2020. Analytical reference/ed. Kashanin A.V., CRSP. Retrieved from: lwpcontent/uploads/2019/11/realnost-vs-DoingBusiness-2020-e. pdf (In Russ.).

[17] 2019 Edelman Trust Barometer, Global Report, Retrieved from: //https://www.edelman.com/sites/g/files/aatuss191/ files/201902/2019_Edelman_Trust_Barometer_Global_Repo rt.pdf

[18] Materials from the official resource of the Ministry of economic development of Russia were Used, Retrieved from: https://fcp.economy.gov.ru/cgibin/cis/fcp.cgi/Fcp/ViewFcp/View/2020/410/ (accessed 30.10.2020) (In Russ.)

[19] The Concept of information policy of the judicial system for 2020-2030 (approved by the Council of judges of the Russian Federation on December 5, 2019. Retrieved from: //https://www.garant.ru/products/ipo/prime/doc/73 061586 (accessed 30.10.2020) (In Russ.). 